\title{
Chapter 3 \\ Between Illegalization, Toleration, and Recognition: Contested Asylum and Deportation Policies in Germany
}

\author{
Maren Kirchhoff and David Lorenz
}

\subsection{Introduction}

Despite the late acknowledgment of Germany being an "immigration country", migration has been a heated topic throughout the last few decades, with peaks in the late 1980s, the early 1990s and the mid-2010s. This time has been marked by an increasing Europeanization of policies concerning asylum and deportation. Policy developments in this field are thus influenced by political debates and struggles both on the national as well as the supranational level. These controversies and multilevel politics have resulted in a contradictory mixture of restrictive regulations regarding the admission of migrants, as well as increased possibilities for residence. Regulations regarding deportations show a similar ambivalence.

The aim of this article is to contextualize contentions over asylum and migration in Germany during the last few decades. We first review literature as well as (policy) documents, campaign materials, and statistics, in order to describe the development of Germany's asylum and deportation policies. After this general context, which is central to understanding the protests analyzed in this book, we illustrate the decisionmaking authority over asylum, deportation, and stay as specific points of reference for protests. Finally, we sketch the broader protest culture in order to further contextualize contention around asylum and deportations.

\author{
M. Kirchhoff $(\bowtie)$ \\ Institute for Migration Research and Intercultural Studies (IMIS), \\ University of Osnabrück, Osnabrück, Germany \\ e-mail: maren.kirchhoff@uni-osnabrueck.de \\ D. Lorenz \\ Kassel University \& Institute for Social Research, Frankfurt am Main, Germany
}




\subsection{Contentions Over Asylum and Deportation in Germany}

In order to illustrate developments in the field of asylum and deportation in the Federal Republic of Germany, ${ }^{1}$ we must go back to the early 1970s. This was a time, when, following the economic crisis, Germany's "guest worker regime" came to an end. Debates around migration were put on the political agenda in Germany, including specific demands regarding the return of "guest workers" whose stay had been initially conceptualized as temporary (Karakayalı 2008, 169-173). Furthermore, in the late 1970s, several states (Länder) governed by conservative parties (Christlich Demokratische Union Deutschlands, CDU/Christlich Soziale Union, CSU) had started a campaign against the "abuse of asylum," which became a central motif in debates on asylum for the following decades.

Migration was seen as an important policy field in the 1980s, and the public discourse on asylum and deportation became more and more polarized: On the one hand, right-wing actors organized campaigns to stop the admission of foreigners in the context of local and federal election campaigns (Der Spiegel 1982). On the other hand, a marginalized, but nonetheless considerable fraction of the population was in favor of liberal asylum and migration policies and the pro-migrant and anti-racist movement of the 1980s succeeded in establishing long-term influential actors: In the early 1980s-a time of massive anti-deportation protests ${ }^{2}-$ Refugee Councils (Flüchtlingsräte) were established on the state level. In the run-up to the 1987 federal elections, a nationwide lobbying group, Pro Asyl was founded, consisting of refugee councils, church representatives, unions, and human rights organizations. These groups attempt(ed) to constitute a voice countering the anti-migrant discourse, and to influence parliamentary decisions. At the same time, they directly support(ed) asylum seekers and migrants with precarious legal status, often via legal means (Müller 2010, 148-149), and continue to be major non-parliamentarian actors in migration politics in Germany (see also below in the part on protest culture).

In 1982 diverging positions regarding security, social and economic policy led to the collapse of the social-liberal coalition (composed of the Sozialdemokratische Partei Deutschlands, SPD \& the Freie Demokratische Partei, FDP). Following the anti-migrant focus of the 1980 federal election campaign, the new conservativeliberal government (CDU/CSU \& FDP) put important policy changes into place in the early and mid 1980s, including the maintenance of the recruitment ban, a restriction on family reunification and the promotion of assisted "voluntary" return. Even though the government continued to deny that Germany was an "immigration

\footnotetext{
${ }^{1}$ When talking about the era before the 1990s, we refer to the Federal Republic of Germany, as the scope of the West German Asylum and Foreigners Acts was extended to East Germany with reunification in October 1990 (Herbert 2003, 297).

${ }^{2}$ In 1983, Kemal Altun, an asylum seeker from Turkey, committed suicide during his court process in order to escape his likely deportation. Subsequently, mass protests against the deportation of political activists with more than 10,000 people took place; this was a decisive moment of politicization for many migrant initiatives and anti-racist groups (Seibert 2008, 187).
} 
country," incentives for return were combined with the concept of "integration" for the first time. This mix was characteristic of the following decades and led to a particular discursive connection between deportation and integration still valid today: deportations of undesired migrants are presented as a way to make room for those considered desirable (Oulios 2013, 220). Furthermore, asylum procedures, residence requirements and collective accommodation were restructured, and work permits for asylum seekers were restricted in the early 1980s. These changes also served as the roots of regulations regarding "safe third countries" and "safe countries of origin" and initial restrictions on asylum: applications referring to a general emergency or war could from now on be swiftly rejected (Müller 2010, 159).

The breakdown of the socialist states in 1989-1990 fundamentally changed the background of the debate on asylum. The context of the Cold War had led to a highly ambivalent position among conservative groups regarding asylum seekers from socialist states, as they were seen as evidence of success in the global competition between capitalism and socialism (Bade and Oltmer 2004, 106). Furthermore, asylum seekers, now increasingly coming from the Global South, were considered potentially problematic migration. As a consequence, the discourse on "bogus asylum seekers" who "abused" the "generosity" of the German asylum system grew in the early 1990s, with increasing discussions on limited capacities and the costs of reception (Müller 2010, 159-161). "Overforeignization" (Überfremdung) became one of the dominant topoi. As a response, restrictive asylum policies found increasing public and parliamentary support (Der Spiegel 1990). Yet, in 1990 this was still far from being a (parliamentarian) majority position.

In the following years, laws restricting asylum gained support, resulting from political developments both on the national and supranational level. In the early 1990s, more and more people sought protection from the wars in former Yugoslavia. The rising numbers of asylum applications were accompanied by an escalation of the discussions of further policy changes. Increasing hostility to "foreigners" contributed to the electoral success of right-wing parties in several state-level parliaments, as well as attacks on migrants in the street and arson attacks on their homes and accommodation (Bade and Oltmer 2004, 108-110). Following one of the most contentious political debates in post-war Germany-as well as strategic negotiations on the European level (Kannankulam 2014, 110), the conservative-liberal government finally agreed with the Social-Democratic opposition on the so-called Asylum Compromise (Asylkompromiss) in December 1992. The majority of the German population backed this (Oulios 2013, 226). Nevertheless, a strong opposition made its dissent public: In 1992, hundreds of thousands of people took part in demonstrations against the asylum reform; in May 1993 10,000 people blocked the government quarter in Bonn (Die Zeit 2012), but could not prevent the law from entering into force.

In order to demarcate itself from its national-socialist past, the right to asylum in Germany had not only been grounded on the basis of international obligations emerging from the Geneva Refugee Convention of 1951, but also had constitutional status since 1949, stating: "Persons persecuted on political grounds shall have the right of asylum." (Basic Law, Grundgesetz, GG). The amendment of the Basic Law 
and the Asylum Procedure Act fundamentally restricted the right to asylum. The physical route asylum seekers took to Germany became one of the key points in their asylum applications: asylum would not be granted if an asylum seeker either came from a "safe country of origin" or if s/he had entered Germany through "safe third countries," which by definition Germany is surrounded. The recognition of refugee status according to the Refugee Convention thus became the most common form of refugee protection, far outnumbering positive decisions regarding asylum on the ground of $\S 16 \mathrm{a} \mathrm{GG}$ (for an overview on the different status of protection, see Table 3.1). An additional result from the Asylum Compromise was the adoption of the Social Welfare Law for Asylum Seekers (Asylbewerberleistungsgesetz, AsylbLG), which excluded asylum seekers from the standard welfare system. ${ }^{3}$ This law allowed mainly for in-kind payment and imposed the primary provision of housing in shared accommodation, forcing the social isolation of persons in pending asylum procedures (Classen and Kanalan 2010, 243).

Following the Asylum Compromise, an overwhelming number of asylum applications were rejected (see Fig. 3.1); their claims of being in danger of persecution were declared unfounded, or were rejected for formal reasons. Consequently, the rejected asylum seekers were obligated to leave the country (Bade and Oltmer 2004, 113). This development was reflected in the German deportation statistics, with a peak of nearly 100,000 deportations from Germany in 1993 (see Fig. 3.2).

In the mid-1990s, the focus of public debates in the field of migration shifted away from trying to close the channels of legal immigration to the return of those migrants who had either entered Germany without permission, had overstayed their visa or had had their asylum claims rejected. While other European countries had granted residence and working permits to migrants fleeing from Bosnia because of civil war, Germany had only provided so called Duldung, which literally means toleration. The status as a temporary suspension of deportation is a characteristic feature of Germany's migration regime even today. Following the Dayton Peace Agreement in December 1996, migrants from Bosnia were supposed to return to that country. While it was not possible to deport all of these people, the combination of high numbers of deportations, the strict and uncompromising enforcement in representative cases, and financial incentives for return led to the removal of more than half of the Bosnian migrants in Germany (Oulios 2013, 231-234; Ausländerbeauftragte 2001, 81).

Assisted returns were increasingly used, and were presented as a humane alternative to deportations. Correspondingly, 4 years after the deportation peak in 1993, in 1997 a sharp rise in assisted returns is to be observed (see Fig. 3.2). In the following 4 years, more than 330,000 people left Germany with support of state-funded return programs, many to Bosnia and Kosovo (Kreienbrink 2007, 26). While most governmental actors highlighted the need for resolute return policies, the enforcement of deportations was highly contested, with a growing number of church

\footnotetext{
${ }^{3}$ The system was extended from asylum seekers to tolerated migrants (in 1997) and in the context of new residence types introduced in the Immigration Act to further groups in 2005 (see Classen and Kanalan 2010, 243).
} 
3 Between Illegalization, Toleration, and Recognition: Contested Asylum...

Table 3.1 Selected status and respective residence permits according to German legislation, prior to changes in 2015/2016

\begin{tabular}{|c|c|c|c|}
\hline & Status & Residence Permit & \\
\hline & $\begin{array}{l}\text { Pending asylum } \\
\text { application }\end{array}$ & $\begin{array}{l}\text { Permission to remain in the federal territory while } \\
\text { the asylum procedure is pending ( }(55 \mathrm{AsylG})\end{array}$ & \multirow{8}{*}{ 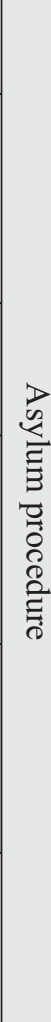 } \\
\hline & $\begin{array}{l}\text { Inadmissability of } \\
\text { application (e.g. due } \\
\text { to Dublin Procedure) }\end{array}$ & $\begin{array}{l}\text { Permission to remain in the federal territory } \\
\text { expires } \\
\text { Requirement to leave the territory ( } \$ 50 \text { AufenthG) } \\
\text { [Possibility to appeal] }\end{array}$ & \\
\hline \multirow{4}{*}{ 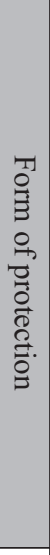 } & Entitlement to asylum & \multirow{2}{*}{$\begin{array}{l}\text { Residence permit for three years, permanent } \\
\text { residence permit possible after three years }(\$ 25 \& \\
\S 26 \text { AufenthG) }\end{array}$} & \\
\hline & Refugee protection & & \\
\hline & \begin{tabular}{|l} 
Subsidiary protection \\
\end{tabular} & $\begin{array}{l}\text { Residence permit for one year, with possible two- } \\
\text { year extension per filing; permanent residence } \\
\text { possible after five years [including the duration of } \\
\text { the asylum procedure] if other preconditions are } \\
\text { met }(\$ 25 \& \S 26 \text { AufenthG) }\end{array}$ & \\
\hline & $\begin{array}{l}\text { National ban on } \\
\text { deportation }\end{array}$ & $\begin{array}{l}\text { Residence permit for at least one year, repeated } \\
\text { extensions possible; settlement permit possible } \\
\text { after five years [including the duration of the } \\
\text { asylum procedure] if other preconditions are met } \\
(\$ 25 \& \S 26 \text { AufenthG) }\end{array}$ & \\
\hline & $\begin{array}{l}\text { Application judged as } \\
\text { manifestly unfounded }\end{array}$ & \multirow{2}{*}{$\begin{array}{l}\text { No residence permit } \\
\text { Requirement to leave the territory ( } \$ 50 \text { AufenthG) } \\
\text { [Possibility to appeal] }\end{array}$} & \\
\hline & Application rejected & & \\
\hline & $\begin{array}{l}\text { Temporary suspension } \\
\text { of deportation } \\
\text { (Duldung) }\end{array}$ & $\begin{array}{l}\text { No residence permit } \\
\text { Suspension for as long as deportation is impossible } \\
\text { in fact or in law and no temporary residence permit } \\
\text { is granted, this does not effect the obligation to } \\
\text { leave the territory ( } \$ 60 \text { a AufenthG) }\end{array}$ & \\
\hline & Case of hardship & $\begin{array}{l}\text { Residence permit may be granted if a Hardship } \\
\text { Commission decides to file a hardship petition } \\
\text { after establishing that urgent humanitarian or } \\
\text { personal grounds justify the foreigner's continued } \\
\text { presence in the federal territory ( } \$ 23 \mathrm{a} \text { AufenthG) }\end{array}$ & \\
\hline & $\begin{array}{l}\text { Granting of residence } \\
\text { due to "sustainable } \\
\text { integration" }\end{array}$ & $\begin{array}{l}\text { Residence permits can be granted to juvenile or } \\
\text { adolescent as well as adult foreigners whose } \\
\text { deportation has been suspended if certain } \\
\text { preconditions are met ( } \$ 25 \text { a \& b AufenthG) }\end{array}$ & \\
\hline
\end{tabular}

Source: Compilation by the authors based on AsylVfG, version: 12/1/2013 and AufenthG, version: 12/2/2013) 


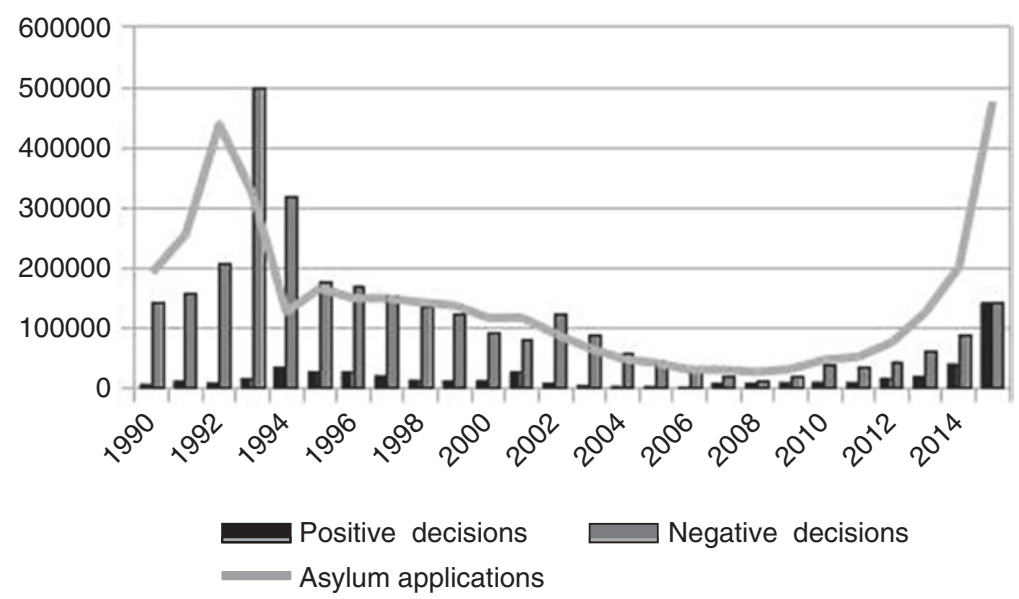

Fig. 3.1 Asylum applications and decisions in Germany, 1990-2015. Based on BAMF 2013, 2014, 2016a; Beauftragte für Migration, Flüchtlinge und Integration 2003 (Positive decisions include entitlement to asylum, refugee status and subsidary protection as well as national bans of deportation, negative decisions refer to rejected applications and applications declined for procedural reasons.)

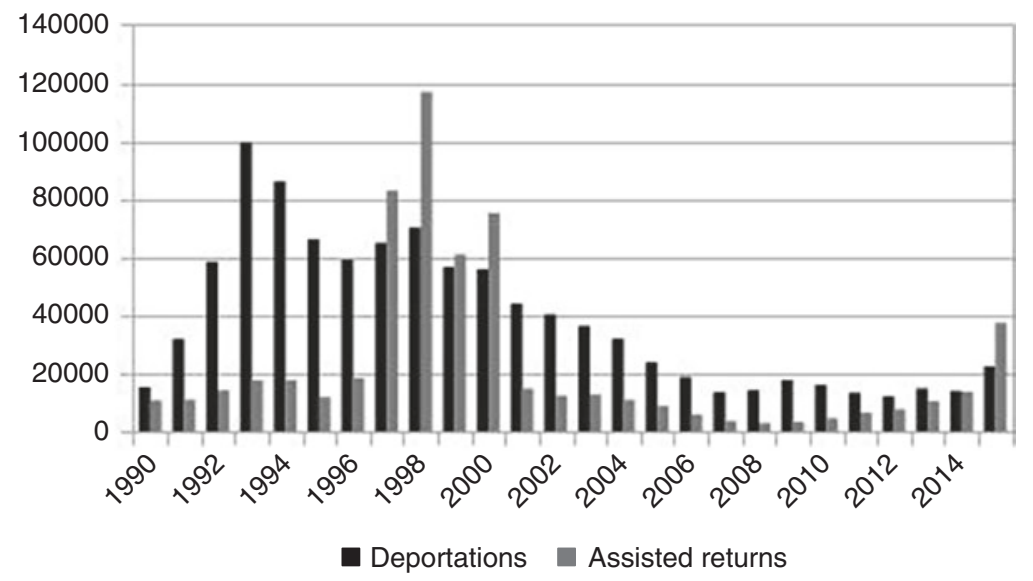

Fig. 3.2 Deportations and assisted returns from Germany, 1990-2015. Based on BAMF 2016b; Deutscher Bundestag 2016; IOM Deutschland 2014; Kreienbrink 2007. (The number of deportations in this Figure is the sum of the official numbers of deportations (Abschiebungen) and rejections (Zurückschiebungen) for each year.)

sanctuaries and public protests. In these, but also the following years, deportation moratoria were frequently put in place during the winter (Flüchtlingsrat BadenWürttemberg 2013).

Furthermore, discussions began around what to do with those who could not be returned (Müller 2010, 168-169). Many migrants could not be deported: some avoided or hid from government enforcement, and others managed to prove that 
their deportation was prohibited. Some rejected asylum seekers were tolerated "as long as deportation is impossible in fact or in law" (\$60a (2) AufenthG) due to different reasons such as the unavailability of identification papers or internal conflicts in the home country. Many people remained without legal regularization, trapped by the toleration of their unlawful presence on German territory. Consequently, there was a considerable population of tolerated people who lacked access to the most fundamental social rights: more than 250,000 tolerated migrants were registered on 12/31/2000 (Ausländerbeauftragte 2001, 81). In an effort to end again and again recurring temporary suspensions of deportation, several backlog regulations have been passed since 1996. However, only a small number of those eligible have actually received a residence permit based on these regulations because of strict criteria. These backlog regulations were supposed to be accompanied by an increase in deportations of rejected asylum seekers (Müller 2010, 168-171).

In October 1997, the Amsterdam Treaty transferred migration and asylum policies into the first pillar of the European Union. The aim was to create a common asylum system based on the comprehensive application of the Geneva Refugee Convention. This entailed an integration of the Schengen Acquis as well as the Dublin Convention into the common laws. The subsequent externalization of the European "Border Regime" (see Hess and Kasparek 2010) and the implementation of the Dublin System-together with the end of the Balkan civil wars-contributed to a significant decrease of asylum applications in Germany (see Fig. 3.1). Furthermore, several EU directives were passed in order to harmonize national laws. ${ }^{4}$

The end of the conservative-liberal coalition and the inauguration of a SocialDemocratic-Green government in 1998 led to a shift towards more liberal migration policies. Examples included new naturalization regulations (1999), the announcement of the Green Card Initiative (2000) and the acknowledgement of Germany as an "immigration country" (Kannankulam 2014). However, conservative actors remained influential, and managed to succeed in making their mark on legislation under the new government. ${ }^{5}$ The focus on labor migration was also reflected on the European level with discussions on a European Blue Card. In the years, migration debates most often referred to the mobility of highly educated workers (Geiger and Hanewinkel 2014). Furthermore, migration was framed in a securitized way following the attacks of 9/11/2001 (Gibney and Hansen 2005, xxi). Considerations of employability and security have remained influential in asylum and migration discourses up to today.

\footnotetext{
${ }^{4}$ E.g. the Directive on minimum standards on procedures in Member States for granting and withdrawing refugee status (Council Regulation 2005/85/EC) or the Directive on minimum standards for the qualification and status of third country nationals or stateless persons as refugees or as persons who otherwise need international protection and the content of the protection granted (2004/83/EC).

${ }^{5}$ This is partly connected to the federalist structure of the political system. To be passed, some laws need the support not only of a majority of the German lower house (Bundestag), but also of the upper house (Bundesrat). After 2000, the Social Democratic-Green government had a majority in the Bundestag, but not in the Bundesrat.
} 
On 1/1/2005, the Immigration Act (AufenthG) entered into force; it included liberalizations such as the introduction of non-state reasons for persecution as grounds for asylum (for example, gender-related persecution) and residency permits due to serious humanitarian or personal reasons. However, these were discretionary provisions that entailed several restrictions. Moreover, the Act introduced stricter requirements for the asylum procedure, and led to the equal treatment of people who had been granted asylum and refugees according to the Geneva Convention, with both now receiving temporary residence permits (Müller 2010, 178-180). Whereas many (pro-)migrant groups had hoped for a general regulation on hardship, the Act (only) provided for the regional possibility of installing hardship commissions (Härtefallkommissionen). These commissions can, but do not have to, take up a specific case. Finally, the decision of a hardship commission is only a recommendation-the final decision lies with the respective Ministries of the Interior-and there is no possibility to appeal their decision (BMI 2016, 180). The hardship regulation thus does not confer subjective rights, but provides for a "power of pardon" in exceptional cases. Despite some improvements entailed by the Immigration Act, the positive expectations of many migrant and refugee (support) organizations resulted in frustration (Schuster 2003, 218). The anti-migrant consensus created in the debates on asylum in the 1980s and 1990s remained influential. The passing of the Immigration Act signaled a shift away from a highly repressive migration policy towards neoliberal migration management underpinned by utilitarian considerations. Yet this shift took several years of negotiations, as it was strongly contested, and only possible against the background of demographic change and a skills shortage in German society (Kannankulam 2014, 93).

Since the 2000s, the "integration" of migrants became critical in discussions on migration policy and in the policies themselves (Oulios 2013, 242). In November 2006, the Conference of the Ministers of the Interior (Innenministerkonferenz, IMK) decided to legalize the stay of those tolerated people who had lived in Germany for more than 6 years on the day of the IMK decision if they were able to prove they had become "economically and socially integrated". All together 20,000 people (out of around 147,000 applicants) received a residency permit until September 2007 because of these changes.

Following public pressure, the IMK implemented another backlog regulation that was integrated into an amendment of the Immigration Act in 2007 (Müller 2010, 180). This stated that migrants could apply for a residence permit if they had lived in Germany for 8 years (or 6 years for those with children). It was again limited by several exclusionary mechanisms. ${ }^{6}$ Due to these changes to the statutory backlog regulation, another 38,000 people received a residence permit. Still, the number of migrants whose deportations were suspended continued to increase ${ }^{7}$ due to the temporary character of this regulation (Oulios 2013, 238).

\footnotetext{
${ }^{6}$ E.g. applicants have to prove that they have enough living space and income to support themselves without access to government funds ( $\$ 104 \mathrm{a} \& \mathrm{~b}$ AufenthG).

${ }^{7}$ On $1 / 1 / 2010$, more than 100,000 people in Germany were tolerated, 60,000 of them for more than six years (GGUA 2010, 5).
} 
The first regulation granting residence to young, long-term tolerated migrants without a time limit was introduced in 2011: A residence permit was to be granted to "well integrated young people and adolescents" if they had lived in Germany for 6 years $^{8}$ (AufenthG, version: 7/1/2011). Based on the applicant's education performance and living conditions, administrative staff would have to forecast if "he or she will be able to integrate into the way of life which prevails in the Federal Republic of Germany" (ibid.). Moreover, non-cooperation in one's own deportation is considered a reason for denying residence permits. Interestingly, this option is detached from the residence status of the youth's parents, who are, however, able to be granted a subsequent residence permit under certain conditions. While the regulation was considered an important step, it has been criticized as being geared towards economic rather than humanitarian interests. Pro Asyl thus underlined the need for an unconditional right to residence as well as to expand the regulations to sans papiers (Pro Asyl 2010, 4-6).

Parallel to this development on the national level, the European integration process increasingly influenced asylum and migration politics and policies in Germany. In March 2003, the Dublin Convention was replaced by the Dublin II regulation. The biometric fingerprint database EURODAC, introduced with Dublin II, was particularly influential, enabling administration in all member states to reconstruct travel routes of asylum seekers into the European Union. In the following years, many Dublin transfers were based on this powerful tool. In 2004, the EU was enlarged, which relocated the common European external border further east. The Hague Program (2005-2010) sought to create a common asylum procedure and a consistent legal status for people in need of international protection. However, many member states, including Germany, insisted on retaining strong national control over migration regulation. Despite this, the Council passed several asylum and migration-related directives during these years. Furthermore, the Agency for the Management of Operational Cooperation at the External Borders of the Member States of the European Union (Frontex) was created in 2004 (Council regulation 2007/2004/EC). Since then, the EU states have frequently conducted collective deportations on charter flights through this agency (Oulios 2013, 346). In 2007, the governing Grand Coalition reassessed the Immigration Act, in order to implement 11 EU directives into national law. The amendment also included some further limitations regarding family reunions not connected to the EU directives (Müller 2010, 182). Moreover, border control was assigned the task of refusing entry to asylum seekers coming from "safe third countries" or a country responsible for their application according to the Dublin II regulation (§18 (2) AsylG).

In 2008, the European Return Directive (Council regulation 2008/115/EC) was passed. Among other aspects, it included possibilities to bring people into custody, to secure deportation and a re-entry ban up to 5 years. While the passing of the Directive led to protests in several European countries-especially in France against the "directive de la honte" (directive of disgrace)-in Germany, mobilization stayed away, presumably because of the little deterioration compared to the already-existing

${ }^{8}$ In 2015 this was reduced to four years ( $\$ 25 \mathrm{a}$ AufenthG). 
return regulations and practices. In the following years, Germany's Residence Act was amended several times to transpose the Directive into national law. However, the few pro-migrant changes the Directive entails, such as an effective monitoring system for deportations or alternatives to deportation detention, have hardly been considered. Accordingly, in 2014, Germany was criticized harshly by EU Commissioner for the Interior (Keßler 2014, 416). In the same year, following a complaint of several detainees pending deportation supported by Pro Asyl and the Jesuiten Flüchtlingsdienst, the European Court of Justice (ECJ) decided that a reform of custody policies in Germany would be necessary to comply with the Return Directive. Both the ECJ and the German Federal Court found a violation of the "separation rule" of the Return Directive, according to which deportation prisoners were to be accommodated exclusively in special facilities. This was especially relevant for persons in Dublin cases who had to be released (Pro Asyl 2014).

At this point in time, the European/German border regime came under pressure from several developments that were partly connected to each other. In late 2010/ early 2011, a number of states in Northern Africa that had previously acted as externalized gatekeepers to the European Union ceased to stop migrants on their way to Europe due to strong political upheavals. This was paired with increasing arrivals through the Balkan corridor. As such, the numbers of asylum applications started to rise again, in particularly after 2012 (see Fig. 3.1). After several years of being low on the political radar, asylum and migration became a publicly contested issue once again, coinciding with the widespread media attention of the refugee protests in 2012 (see Odugbesan and Schwiertz 2018). Despite broad public support, official reactions were either repressive or non-existent (Steinhilper 2016).

Simultaneously, the discourse around the "abuse of asylum" was reactivated by conservative politicians. In 2013, the ruling Grand Coalition agreed to classify the West Balkan states of Bosnia and Herzegovina, Serbia, and Macedonia as safe countries of origin (CDU/CSU \& SPD 2013, 76). Despite these restrictions, asylum applications continued to rise. The temporary collapse of border controls and the broader crisis of the Dublin Regime, as well as the escalating wars in Syria, Iraq, and Afghanistan, resulted in the number of asylum applications in 2015 reaching nearly $480,000^{9}$ (BAMF 2016a, 10).

At this time, broader parts of society became engaged with the topic of asylum and migration. On the one hand, there was an increase in anti-migrant discourse and actions: The new right-wing populist party Alternative for Germany (Alternative für Deutschland, AfD), founded in 2013, gained considerable support in state elections in 2014-2015 (see Rucht 2018). In the same time frame, the numbers of racist attacks against refugee accommodation centers and people perceived as foreigners rose sharply. This led to an escalation of the public discourse comparable to the anti-migrant discourses in the early 1990s. On the other hand, and in contrast to the 1990s, the increased pro-migrant mobilization now included a broader spectrum

\footnotetext{
${ }^{9}$ The actual number of entries is significantly higher. Due to a lack of capacity, the process has been characterized by delays (BAMF 2016a, 10).
} 
of society. Particularly in the summer of 2015 , uncountable volunteers supported refugees, providing services the state failed to provide.

In September 2015, some European member states opened a humanitarian corridor for people arriving in Greece to travel to Germany. In contrast to the peak in applications in 1992, a significant share of applications was accepted: In 2015, more than half of the asylum decisions led to international protection of the applicants (see Fig. 3.1). This moment of openness was soon accompanied by another increase in legislative restrictions: On 8/1/2015, the new Residence Act (Gesetz zur Neubestimmung des Bleiberechts und der Aufenthaltsbeendigung, AufenthG) entered into force. It entailed changes to facilitate and accelerate the enforcement of deportations, including the reinstallation of custody procedures (Pro Asyl 2015). It also contained some key liberalizing elements, though, as for the first time there was a legal option for those who had been tolerated for a long period of time to apply for a residence permit independent of length of stay or age restrictions ( $\$ 25 \mathrm{~b}$ AufenthG).

In reaction to the large numbers of asylum seekers that had reached Europe and Germany in August and September 2015, the Asylum Procedure Acceleration Act (Asylverfahrensbeschleunigungsgesetz, Asylum Act) was passed in October 2015. This act entailed several changes to existing laws, such as the prohibition of announcing a date for deportation once the limit for assisted return had expired and the classification of Albania, Kosovo, and Montenegro as "safe countries of origin". Asylum seekers arriving from these countries would now have to stay in initial reception centers until the end of their asylum application process or until their departure in the case that their claim was rejected. These changes also reduced the time for complaints or appeals against asylum decisions. ${ }^{10}$ All in all, these changes in asylum laws can be seen as the most encompassing restrictions since the early 1990s.

This overview shows that migration (policy) has been highly contested throughout the last decades. This led (and still leads) to ambivalent legislation, combining liberalizations with restrictions, which influence the scope of contestation over asylum and deportation. In order to understand the specific context for such struggles, we will now focus on the (political and) administrative decision-making authority in this field.

\subsection{Administrative Decision-Making Authority}

The main laws regulating asylum, deportation, and stay/residence are the Asylum (Procedure) Act (Asyl(verfahrens)gesetz, Asyl(Vf)G) ${ }^{11}$ and the Residence Act (AufenthG). In general, administrative authorities on the municipal, state, and federal level are responsible for the majority of decisions regarding asylum, depor-

\footnotetext{
${ }^{10}$ Ultimately, it included changes in the AsylbLG, most importantly the return to payment in-kind ( 33 (1) AsylbLG) and a restriction on access to benefits ( $\$ 1$ a AsylbLG).

${ }^{11}$ In Oktober 2015, the new Asylum Act replaced the former Asylum Procedure Act.
} 
tation, and stay. However, the Asylum Act and the Residence Act allow for temporary political decisions to be made by political governmental agencies, mostly on the state level, but also on the federal level. Administrative decision-making authority is highly complex due to the multiple levels involved. Competences may also differ between the different states and have been shifted between levels. In the following, we describe administrative authorities for decision-making prior to the changes of 2015/2016, ${ }^{12}$ and do not go into regional details or changes over time.

Decisions over asylum applications are made by the federal administration: the Federal Office for Migration and Refugees (Bundesamt für Migration und Flüchtlinge, BAMF), which is affiliated with the Federal Ministry of the Interior as the higher federal authority. Prior to the examination of an asylum application, the BAMF checks responsibility for the asylum application according to the Dublin regulation. In case an asylum procedure is processed or completed in another member state, the BAMF files a transfer request. ${ }^{13}$ In case Germany is responsible for the asylum application, the BAMF examines different forms of protection in an individual procedure: first, it checks entitlement to asylum, refugee protection and subsidiary protection when none of the former forms of protection is granted, a national ban on deportation $(\S 60(5)+(7)$ AufenthG) can be issued if specific grounds apply (see Table 3.1). Asylum applicants have the permission to reside for the length of the pending asylum procedure. When the procedure is terminated, the four different protection statuses result in different entitlements with regards to residence permits. This decision is binding and cannot be revoked.

In the case of a negative decision, the BAMF serves a deportation warning in combination with the rejected claim ( $\$ 34$ AsylG). Asylum seekers whose application has been judged as inadmissible or been rejected can file court cases against the BAMF decision within a short time frame. They may not be deported or transferred until the ruling has been handed down.

According to the Residence Act, state-level Immigration Authorities acting as higher state-level authorities are in charge of decisions surrounding the specific enforcement of deportations. However, in the case of rejected asylum seekers, the BAMF, as a federal agency, decides on whether a person should be deported. Nevertheless, it is still up to the state Immigration Authority to decide upon the actual enforcement of the deportation. The Immigration Authority organizes the deportation, but its physical enforcement is carried out both by state and federal police. If conflicts arise, the Immigration Authority is dependent on the local police, subordinated to the state Ministry of the Interior, to enforce the deportation order. This divided authority may open up the scope for direct action against deportation (see Hinger et al. 2018).

\footnotetext{
${ }^{12}$ The German cases analyzed in the remainder of the book (see Hinger et al. 2018; Kirchhoff et al. 2018) occurred before 2015/2016. For an overview on policy changes in $2015 / 2016$ see Pichl 2017.

${ }^{13}$ If the transfer is not carried out within 6 months (extended in case of detention or if a person is not traceable), responsibility for the asylum procedure is transferred to the German authorities.
} 
The Immigration Authority can assign a temporary suspension of deportation to people whose deportation is impossible in fact or in law. Even though the state Immigration Authorities are legally responsible, most states delegate this responsibility to the municipal Immigration Authorities (Bogumil and Jann 2009, 104). Whereas general decision-making authority lies at the state and federal level, the scope for decision-making on the municipal level should not be underestimated, as the Residence Act includes several discretionary clauses. Finally, and adding another layer of complexity, most of the deportations from Germany are carried out by passenger flights on private airlines. Once the doors of an airplane close, the pilot has the legal authority and can decide whether or not to carry out a deportation. This extra-state decision-making power has been a leverage point for protests against deportations at airports (Seidlmayer 2012).

As mentioned above, the law confers political decision-making power on the state Ministers of the Interior and the federal Minister of the Interior as the highest federal and state authorities responsible for this policy field. Examples of this include the collective deportation moratoria in winter or hardship decisions. In the latter case, hardship commissions on the state leve ${ }^{14}$ decide if a residence permit should be granted on humanitarian grounds. The responsibility for final decisions in hardship cases lies with the respective Ministry of the Interior of the state. Furthermore, the state and federal Ministries of Interior can take charge of deportation proceedings "if a special interest on part of the Federation applies" ( $\$ 58 \mathrm{a}$ AufenthG). The most frequent political decisions regarding the implementation of the Residence Act are taken by the Conference of the Ministers of the Interior. In their semi-annual meetings, resolutions have to approved by consensus (IMK 2016).

Courts also play an important decision-making role. In general, appeals of administrative procedures or decisions are directed to state-level administrative courts. ${ }^{15}$ They decide, for example, whether the rejection of an asylum claim is valid, whether a Dublin transfer is in accordance with human rights, or on detention. In the last years a great share of BAMF decisions has been revised through administrative court decisions. The regional administrative courts handle everyday decisions. Furthermore, some appeals can be lodged at the Federal Constitutional Court (Bundesverfassungsgericht, BVerfG), the highest legal authority in Germany. If constitutional rights are at risk, the BVerfG can declare provisional legal protection, e.g. against deportations. The enforcement of the deportation order is then stopped until a final court decision has been made. This happened, for example, in the case of a Dublin transfer to Greece in 2009; in the following court proceedings, the BVerfG suggested the government to stop all Dublin transfers to Greece. In order to

\footnotetext{
${ }^{14}$ States have autonomy over how the commission is formed and proceeds. The hardship commission in Hamburg is, for instance, formed by representatives of every party elected to the state parliament and all decisions had to be unanimous until a change in regulations in 2015 (HFKG $§ 1$ \& $\S 5$ ). In contrast, the hardship commission in Lower Saxony is composed of a variety of actors, including state representatives, a medical practitioner, representatives of the church, and the Refugee Council and decides by majority vote (NHärteKVO §2 \& §6).

${ }^{15}$ In the case of social welfare, pleas can also be directed to social courts (Classen 2008, 229-239).
} 
avoid a decision before the BVerfG, the Ministry of Interior declared that they would not carry out any further deportations to Greece until the situation of the asylum system and the living conditions in Greece had improved (Meyerhöfer et al. 2014, 161).

On the European level, it is the European Court of Human Rights (ECtHR) and the European Court of Justice (ECJ) that are involved in decisions concerning deportations. The ECtHR judgements are based on the European Convention on Human Rights (ECHR); however, decisions are only legally binding in the specific states involved in the court case. In January 2011, the ECtHR declared that a Dublin transfer of one person from Belgium to Greece violated Article 3 (torture and inhuman or degrading treatment or punishment) and Article 13 (effective remedy) of the ECHR. Following this decision, most of the member states of the European Union stopped Dublin transfers to Greece (ibid., 163). The ECJ is the highest legal authority in matters of European Union law. Its decisions are legally binding for all member states and their courts. National or federal courts can submit cases to the ECJ if the case concerns European law. In the field of deportation, it is the enforcement of Dublin transfers that is a regular matter for the ECJ.

As we have shown, administrative and political decision-making authority is highly complex due to the multiple levels involved. This is complemented trough a strong judiciary. While this complexity may be confusing for those confronted with state decissions concerning asylum and deportation, it provides different entry points and scope for contestation of such decissions. We will now sketch the protest culture in the Federal Republic of Germany in order to further contextualize protests in this field.

\subsection{Protest Culture}

The Federal Republic of Germany has been characterized as a "movement society." Participation in social movements, political campaigns, citizens' initiatives, and protest groups all form part of the political repertoire, as does membership to political parties, associations, and other institutionalized organizations (Roth and Rucht 2008, 10). Between 1950 and 1994, the average number of protests and the number of protest participants increased (Hutter and Teune 2012, 11-12). Protests as a means to express one's political opinion were increasingly accepted and spread from big organizations such as unions to smaller, more local, and partly informal groups (Neidhardt and Rucht 2001,36). Local and regional mobilization greatly exceeds national protest mobilization. Protest forms such as demonstrations, but also direct actions like blockades and occupations, have increased disproportionally. While judicial forms of protests have comparatively been small in number, they may have nevertheless had a significant impact on the outcome of several conflicts (ibid., 51-55). Even though protest mobilization at the end of the 1990s and the 2000s was more moderate than in the 1980s and early 1990s, protests remain "a standard repertoire of politically active persons" (Hutter and Teune 2012, 12). 
The relevance of protest participation has to be seen, in part, against the background of the political system in Germany. This system provides few access points for challengers despite its federalist structure and strong judiciary; policy decisions are based on representative democracy, with very few direct-democratic elements (Kriesi et al. 1992, 222-224).

In the late 1980s and early 1990s, migration became one of the most contested issues in the reunified Germany. As described above, at that time the government was in the hands of a conservative-liberal government. Still, the pro-migrant protest movement succeeded in consolidating its interests, with the establishment of influential organizations such as Pro Asyl and the Refugee Councils, thereby exerting its influence far beyond the protest cycle of the 1980s. Since then, both institutionalized structures have had a relatively high proximity to protest movements compared to NGOs in other countries. These institutions continue to be important resources in the political struggle for asylum and against deportations in Germany. In contrast, protest movements against asylum seekers have no equivalent institutionalized counterpart (see Rucht 2018).

In the first half of the 1990s, one-third of all protests were related to migration (Neidhardt and Rucht 2001, 40-42). Up until this point, protests had mainly been composed of actors from the liberal or radical left, but from the 1990s onwards, the radical right gained in importance (Hutter and Teune 2012,15). The increase in the number of militant radical right-wing protests against migrants, though, was outnumbered by pro-migrant protests which mobilized a broad spectrum, from left anti-fascist groups to the middle classes (Roth and Rucht 2008, 34). Since the new wave of anti-migrant protest by PEGIDA and related groups that began in 2013 anti-migrant protests have started to catch up with numbers of pro-migrant protests (see Rucht 2018, 246).

The number of migrants participating in protests on the issue of migration especially increased in the early 1990s (Neidhardt and Rucht 2001, 49). At this time, several pro-migrant initiatives were founded. The focus of these initiatives was less to influence policy processes, but to counteract the consequences of these policies. In contrast to mass demonstrations, forms of direct action and disruption gained importance. In 1994, five African asylum seekers founded The Voice Refugee Forum to protest against isolation prescribed by the new asylum laws. In the same year, the federal working group on church sanctuary BAG Asyl in der Kirche was founded to ensure further examination of rejected asylum cases (Kirchhoff 2017, 51). This also underlines the importance churches have played in contention over asylum and deportations since the early 1980s.

In order to highlight the highly precarious status of illegalized migrants and to connect anti-racist and church groups in their support of such persons, the Germanwide initiative no one is illegal (kein mensch ist illegal, kmii) was founded during the documenta international art exhibition in 1997. kmii appealed for direct support of migrants, "the provision of work and identity papers [...], the supply of medical care, education and training, accommodation, and material survival" (kmii 2017). Still, the aim to influence public opinion was hardly abandoned; kmii directly attacked the image of Lufthansa by pointing to their involvements in deportation 
enforcement, applying new forms of "communication guerrilla warfare" with the deportation.class campaign (Kirchhoff 2017, 51).

Furthermore, protests continued to address policymakers. In the run-up to the German federal elections in 1998, the Caravan for the Rights of Refugees and Migrants, an organization of migrants with various residency statuses as well as German citizens, mobilized a country-wide tour to gain visibility and call for "sociopolitical justice, equality and respect for the fundamental human rights of everyone" (The Caravan Berlin 2013). In 2005, Youth without Borders (Jugendliche ohne Grenzen) was founded, demanding a right to stay for all. The group regularly protests during the conference of the state Ministers of the Interior, which repeatedly decides on provisions regarding deportations, but also on possibilities to stay (see Odugbesan and Schwiertz 2018).

The refugee protests of 2012 relied on this strong tradition of self-organization of migrants and asylum seekers as well as pro-migrant organizations. They succeeded in becoming visible and raising public awareness of their demands (Jakob 2016, 8-18). In addition, in 2014 and 2015, the numbers of people volunteering to support the newly arrived persons peaked. Several authors (Kanalan 2015; Jakob 2016) have argued that this increase needs to be understood against the background of the visibility that refugees and migrants gained through the refugee protests since 2012. It might be worth further analysis about how far voluntarism has become established as a new form of political activism, as this potentially depicts a further shift in the changing protest culture of the Federal Republic of Germany.

\subsection{Conclusion}

The discussion about asylum and migration has been one of the fiercest societal debates in the history of (Western) Germany since the 1980s and continues to be so today. In the context of racist mobilizations and "moral panic" about the "abuse of the asylum system" (Kannankulam 2014, 102), conservative political actors succeeded in setting the agenda of a restrictive migration and asylum policy, which culminated in the Asylum Compromise of the newly reunified Germany. This was countered by (pro-)migrant mobilizations, the foundation of several self-organized initiatives of (rejected) asylum seekers, and support from German citizens, promigrant NGOs, and churches. While this broad network of (pro-)migrant mobilization could hardly influence policy making in the field during the late 1980s/ early 1990 s, it can be seen as a structural basis for protests challenging the implementation of restrictive asylum (and migration) policies including protests against deportation until today.

Since the early 2000s, at a time of rather low numbers of asylum applications, Germany started to be officially acknowledged as an "immigration country." This has been reflected by an increasing amount of regulations that grants residence to migrants who have stayed in Germany for a long time, often under extremely insecure conditions. This shift can be understood as a reaction to the strong organization 
by and for migrants, as well as a general shift away from conservative migration policy agendas and towards a new economic logic of migration management. However, as a concession to conservative positions, the restrictive character of asylum and residence laws remains strong. As such, German migration and asylum policy has a highly ambivalent character.

Since the late 1990s and early 2000s, policies in the field of asylum and residency have, contradictorily, been both restricted and liberalized: Possibilities to be granted residence have increased, so did attempts to increase state capacity to deport unwanted migrants as delinquents or "bogus asylum seekers". The actual number of deportations has been relatively limited, due to legal revisions of BAMF decisions or the application of alternative regulations in the Residence Act. In June 2015, 84\% of the formerly rejected asylum seekers possessed either a limited or an unlimited residence permit (Deutscher Bundestag 2015, 29). This may also be interpretated as the result of careful legal support in individual cases. Still, the large number of migrants with a precarious legal status remains one of the characteristic features of the migration regime in Germany.

With the rising numbers of asylum seekers in 2014 and 2015, protests against and for migration increased again. In September 2015, the journalist Sebastian Friedrich stated: "We are in the midst of an open social conflict" (Friedrich 2015, translation by the authors). Again, this open conflict was answered by further restrictions of the asylum laws and the intention to divide between "good" and "bad" asylum seekers, to find a compromise between politics of welcome and of barriers. More than two years later, an end of this social conflict is not in sight. It remains to be seen how the revitalized anti-migrant discourse and violence against migrants as well as the constant (pro-)migrant mobilization will develop and affect both policies and contentions around asylum and deportation in Germany in the long run.

Acknowledgements This paper emerged from the project Taking Sides, which analyzes antideportation protests in Austria, Switzerland and Germany. The project has been funded under the DACH scheme of FWF, SNF and DFG (SCHW1389/5-1). We also thank Marlene Becker, Helen Schwenken, Ricarda Wiese, Helge Schwiertz, Tatjana Ulshöfer, Sophie Hinger, and the editors and anonymous reviewers for their comments, as well as Madelaine Moore and Matt Rees for linguistic revision.

\section{References}

Ausländerbeauftragte. (2001). Migrationsbericht der Ausländerbeauftragten. http://www.bmi. bund.de/cae/servlet/contentblob/149602/publicationFile/15184/migrationsbericht_2001.pdf. Accessed 18 June 2016.

Bade, K. J., \& Oltmer, J. (2004). Normalfall Migration: Deutschland im 20. und frühen 21. Jahrhundert. Bonn: Bundeszentrale für politische Bildung.

Baden-Württemberg, F. (2013). “Winterabschiebestopp” in Baden-Württemberg: Humanität hat Vorrang? http://fluechtlingsrat-bw.de/informationen-ansicht/winterabschiebestopp-jetzt-auchin-baden-wuerttemberg.html. Accessed 1 Aug 2016.

BAMF. (2014). Das Bundesamt in Zahlen 2013. http://www.bamf.de/SharedDocs/Anlagen/DE/ Publikationen/Broschueren/bundesamt-in-zahlen-2013.html. Accessed 12 Oct 2014. 
BAMF. (2016a). Das Bundesamt in Zahlen 2015. http://www.bamf.de/SharedDocs/Anlagen/DE/ Publikationen/Broschueren/bundesamt-in-zahlen-2015.html. Accessed 12 July 2016.

BAMF. (2016b). Migrationsbericht 2014. http://www.bamf.de/SharedDocs/Anlagen/DE/ Publikationen/Migrationsberichte/migrationsbericht-2014.pdf?__blob=publicationFile. Accessed 26 Feb 2016.

BAMF, Bundesamt für Migration und Flüchtlinge. (2013). Das Bundesamt in Zahlen 2012. https:// fragdenstaat.de/files/foi/14716/2013_bundesamt-in-zahlen-2012.pdf. Accessed 18 July 2016.

Beauftragte der Bundesregierung für Migration, Flüchtlinge und Integration. (2003). Migrationsbericht 2003. http://www.bmi.bund.de/cae/servlet/contentblob/149604/publicationFile/15185/migrationsbericht_2003.pdf. Accessed 12 July 2016.

BMI, Bundesministerium des Inneren. (2016). Häufig gestellte Fragen zum Thema: Ausländerrecht. http://www.bmi.bund.de/SharedDocs/FAQs/DE/Themen/Migration/Auslaenderrecht/20.html. Accessed 15 July 2016.

Bogumil, J., \& Jann, W. (2009). Verwaltung und Verwaltungswissenschaft in Deutschland: Einführung in die Verwaltungswissenschaft. VS: Wiesbaden.

CDU, CSU, SPD. (2013). Deutschlands Zukunft gestalten. Koalitionsvertrag. https://www.cdu.de/ sites/default/files/media/dokumente/koalitionsvertrag.pdf. Accessed 28 Oct 2016.

Classen, G. (2008). Sozialleistungen für MigrantInnen und Flüchtlinge. Handbuch für die Praxis. Karlsruhe: Von Loeper.

Classen, G., \& Kanalan, I. (2010). Verfassungsmäßigkeit des Asylbewerberleistungsgesetzes. Informationen zum Arbeitslosenrecht und Sozialhilferecht, 6(2010), 243-249.

Der Spiegel (1982, May 3). Ausländer: "Das Volk hat es satt". http://www.spiegel.de/spiegel/ print/d-14348246.html. Accessed 7 Sept 2016.

Der Spiegel (1990, August 20). Asyl. Letztes Paradies. http://www.spiegel.de/spiegel/ print/d-13501091.html. Accessed 14 Sept 2016.

Deutscher Bundestag (2015). Antwort der Bundesregierung auf die Kleine Anfrage zu Zahlen in der Bundesrepublik Deutschland lebender Flüchtlinge. Drucksache 18/5862. http://dip21. bundestag.de/dip21/btd/18/058/1805862.pdf. Accessed 16 Oct 2016.

Deutscher Bundestag (2016). Antwort der Bundesregierung. Abschiebungen im Jahr 2015. Drucksache 18/7588. http://dip21.bundestag.de/dip21/btd/18/075/1807588.pdf. Accessed 26 Feb 2016.

Die Zeit (2012, November 29). Asylkompromiss von 1992. http://www.zeit.de/2012/49/DebatteGrundrecht-Asyl-1992/komplettansicht. Accessed 14 Nov 2016.

Friedrich, S. (2015). Konflikt statt Konsens: Gegen einen Kompromiss zwischen Rassismus und "Willkommenskultur". http://www.sebastian-friedrich.net/?p=362. Accessed 21 July 2016.

Geiger, M., \& Hanewinkel, V. (2014). Politik der Arbeitsmigration. In P. Gans (Ed.), Räumliche Auswirkungen der internationalen Migration (pp. 162-179). Hannover: ARL. http://shop.arlnet.de/media/direct/pdf/fb/fb_003/fb_003_09.pdf. Accessed 11 Oct 2016.

GGUA, Gemeinnützige Gesellschaft zur Unterstützung Asylsuchender. (2010). Arbeitshilfe: Zur Umsetzung des \$25a AufenthG-Bleiberecht für Jugendliche und Heranwachsende. http://www. asyl.net/fileadmin/user_upload/redaktion/Dokumente/GGUA25a.pdf. Accessed 19 July 2016.

Gibney, M., \& Hansen, R. (Eds.). (2005). Immigration and asylum from 1900 to the present. Volume 1: Entries A to I. Santa Barbara et al.: ABC Clio.

Herbert, U. (2003). Geschichte der Ausländerpolitik in Deutschland. Bonn: Bundeszentrale für politische Bildung.

Hess, S., \& Kasparek, B. (2010). Grenzregime. Diskurse, Praktiken, Institutionen in Europa. Hamburg: Assoziation A.

HFKG, Hamburgisches Gesetz über die Härtefallkommission nach § 23 a des Aufenthaltsgesetzes. (2005, May 4). http://www.landesrecht-hamburg.de/jportal/portal/page/bshaprod. psml? showdoccase $=1 \&$ doc.id=jlr-HFKGHArahmen\&doc. part $=$ X \&doc.origin=bs\&st=lr. Accessed 15 July 2016.

Hinger, S., Kirchhoff, M., \& Wiese, R. (2018). "We belong together!" collective anti-deportation protests in Osnabrück. In S. Rosenberger, V. Stern, \& N. Merhaut (Eds.), Protest movements in asylum and deportation (pp. 171-194). New York: Springer. 
Hutter, S., \& Teune, S. (2012). Deutschlands Protestprofil im Wandel. Aus Politik und Zeitgeschichte, 62(25-26), 9-17.

IMK, Innenministerkonferenz. (2016). Ständige Konferenz der Innenminister und-senatoren der Länder. Aufgaben und Arbeitsweise. http://www.innenministerkonferenz.de/IMK/DE/aufgaben/aufgaben-node.html. Accessed 12 Oct 2016.

IOM Deutschland. (2014). Bericht über die Programme zur Unterstützung freiwilliger Rückkehr der Internationalen Organisation für Migration Deutschland 2013. http://germany.iom.int/ sites/default/files/REAG/AVR_Report_2013.pdf. Accessed 29 Mar 2016.

Jakob, C. (2016). Die Bleibenden. Wie Flüchtlinge Deutschland seit 20 Jahren verändern. Berlin: Ch. Links.

Kanalan, I. (2015). Jugendliche ohne Grenzen. Zehn Jahre Proteste und Kämpfe von Geflüchteten Jugendlichen - Creating Utopia? movements. Journal für kritische Migrations-und Grenzregimeforschung, 1(2). http://movements-journal.org/issues/02.kaempfe/10.kanalan-jugendliche-ohne-grenzen.html. Accessed 3 Aug 2016.

Kannankulam, J. (2014). Kräfteverhältnisse in der bundesdeutschen Migrationspolitik. Die Asyldebatte als Schlüsselereignis des schwerfälligen Wandels vom Gastarbeitsregime hin zu Managed Migration. In Forschungsgruppe Staatsprojekt Europa (Ed.), Kämpfe um Migrationspolitik (pp. 93-112). Bielefeld: Transcript.

Karakayal1, S. (2008). Gespenster der Migration: Zur Genealogie illegaler Einwanderung in der Bundesrepublik Deutschland. Bielefeld: Transcript.

Keßler, S. (2014). Erreichen des Klassenziels gefährdet. Zur (Nicht-)Umsetzung der Rückführungsrichtlinie in Deutschland. Asylmagazin, 12(2014), 416-420.

Kirchhoff, M. (2017). Vor und nach dem Willkommen. Zur Geschichte und Aktualität von Protesten gegen Abschiebungen. In BdWi et al. (Eds.): Krise der EU. Kontroversen - Perspektiven Linke Alternativen (pp. 50-52). Studienheft 11.

Kirchhoff, M., Probst, J., Schwenken, H., \& Stern, V. (2018). Worth the effort: Protesting successfully against deportations. In S. Rosenberger, V. Stern, \& N. Merhaut (Eds.), Protest movements in asylum and deportation (pp. 126-148). New York: Springer.

kmii, no one is illegal. (2017). Manifesto. https://noii2017.wordpress.com/portfolio/manifestoenglish/. Accessed 26 June 2017.

Kreienbrink, A. (2007). Voluntary and forced return of third country nationals from Germany. Research study 2006 in the framework of the European Migration Network. http://ec.europa. eu/dgs/home-affairs/what-we-do/networks/european_migration_network/reports/docs/emnstudies/return-migration/4a._de_emn_ncp_return_country_study_final_may2007en_version_ en.pdf. Accessed 3 Aug 2016.

Kriesi, H., Koopmans, R., Duyvendak, J. W., \& Guigni, M. G. (1992). New social movements and political opportunities in Western Europe. European Journal of Political Research, 22(2), 219-244.

Meyerhöfer, A., Hartl, U., Lorenz, D., Neumann, S., \& Oeser, A. (2014). "Dublin II kippen!" Kämpfe um selbstbestimmte Migration in Europa. In Forschungsgruppe Staatsprojekt Europa (Ed.), Kämpfe um Migrationspolitik (pp. 151-167). Bielefeld: Transcript.

Müller, D. (2010). Flucht und Asyl in europäischen Migrationsregimen. Metamorphosen einer umkämpften Kategorie am Beispiel der EU, Deutschlands und Polens. Göttingen: Göttinger Universitätsverlag.

Neidhardt, F., \& Rucht, D. (2001). Protestgeschichte der Bundesrepublik Deutschland 1950-1994: Ereignisse, Themen, Akteure. In D. Rucht (Ed.), Protest in der Bundesrepublik (pp. 27-70). Frankfurt am Main: Campus.

NhärteKVO, Verordnung über die Härtefallkommission in Niedersachsen nach dem Aufenthaltsgesetz. (2006, August 8). http://www.mi.niedersachsen.de/download/103919/ Niedersaechsische_Haertefallkommissionsverordnung.pdf. Accessed 15 July 2016.

Odugbesan, A., \& Schwiertz, H. (2018). "We are here to stay" - Refugee struggles in Germany between unity and division. In S. Rosenberger, V. Stern, \& N. Merhaut (Eds.), Protest movements in asylum and deportation (pp. 195-214). New York: Springer. 
Oulios, M. (2013). Blackbox Abschiebung. Geschichten und Bilder von Leuten, die gerne geblieben wären. Berlin: Suhrkamp.

Pichl, M. (2017). Die Asylpakete I und II: Der politische und rechtliche Kampf um die Asylverschärfungen. In S. Hess et al. (Eds.), Der lange Sommer der Migration. Grenzregime III (pp. 163-175). Berlin: Hamburg Assoziation A.

Pro Asyl. (2010). Hier geblieben! Anforderungen an eine neue Bleiberechtsregelung. http:// archiv.proasyl.de/fileadmin/fm-dam/a_Startseite_und_Aktionsseiten/Startseite/2011/ Anforderungen_neue_Bleiberechtsregelung_2011.pdf. Accessed 18 July 2016.

Pro Asyl. (2014). Nach EuGH und BGH-Urteil: Ende der Abschiebungshaft oder neues Inhaftierungsprogramm? https://www.proasyl.de/news/nach-eugh-und-bgh-urteil-ende-derabschiebungshaft-oder-neues-inhaftierungsprogramm/. Accessed 26 June 2017.

Pro Asyl. (2015). Bundestag beschließt Ausweitung der Abschiebehaft und Bleiberechtsregelung. https://www.proasyl.de/news/bundestag-beschliesst-ausweitung-der-abschiebungshaft-undbleiberechtsregelung/. Accessed 1 Aug 2016.

Roth, R., \& Rucht, D. (Eds.). (2008). Die Sozialen Bewegungen in Deutschland seit 1945. Ein Handbuch. Frankfurt/New York: Campus.

Rucht, D. (2018). Mobilization against refugees and asylum seekers in Germany: A social movement perspective. In S. Rosenberger, V. Stern, \& N. Merhaut (Eds.), Protest movements in asylum and deportation (pp. 234-255). New York: Springer.

Schuster, L. (2003). The use and abuse of political asylum in Britain and Germany. London: Routledge.

Seibert, N. (2008). Vergessene Proteste: Internationalismus und Antirassismus 1964-1983. Münster: Unrast.

Seidlmayer, E.-L. (2012). Last Minute Protest. Hinterland, 19, 34-37.

Steinhilper, E. (2016). Selbstbewusst und Laut - Politische Proteste von Geflüchteten. In Bundeszentrale für politische Bildung ( $b p b$ ) (Ed.). Kurzdossiers. http://www.bpb.de/gesellschaft/migration/kurzdossiers/227542/politische-proteste-von-gefluechteten. Accessed 18 July 2016.

The Caravan Berlin. (2013). About the Caravan. http://karawane-berlin.org/about-the-caravan/. Accessed 18 July 2016.

Open Access This chapter is licensed under the terms of the Creative Commons Attribution 4.0 International License (http://creativecommons.org/licenses/by/4.0/), which permits use, sharing, adaptation, distribution and reproduction in any medium or format, as long as you give appropriate credit to the original author(s) and the source, provide a link to the Creative Commons license and indicate if changes were made.

The images or other third party material in this chapter are included in the chapter's Creative Commons license, unless indicated otherwise in a credit line to the material. If material is not included in the chapter's Creative Commons license and your intended use is not permitted by statutory regulation or exceeds the permitted use, you will need to obtain permission directly from the copyright holder.

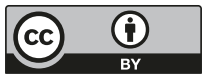

